\title{
SOCIAL RIGHTS IN THE FACE OF THE CRISIS. REFLECTIONS ON THE SPANISH CASE
}

\author{
FERNANDO PUZZO ${ }^{1}$
}

\begin{abstract}
Spain and many European countries are going through a critical stage that endangers the achievements of civilization and protection of social rights which are the standard of the constitutionalism of the social-democratic systems after the Second World War. The emergence of the economic and financial crisis and its impact on Member States, especially in regard to the realization of the rights and, in particular, the social ones, impose a critical reflection since on the European scene there is not a shared concept. In the Spanish social and democratic rule of law, many of the social rights are placed in Chapter III of Title I as guiding principles of social and economic policy. The analysis of this regulatory body of the Constitution is problematic insofar as it raises the problem of redirecting the content of such rules to legal structures in order to ensure guarantee levels which approximate them to fundamental rights within the framework of a European model of social democracy. The problem of the welfare state (in Spain and other European countries) affects the quality of representative democracy.
\end{abstract}

Keywords: Social Rights; Welfare State; Financial Crisis; Crisis of Contemporary Constitutionalism; Democracy.

Summary: I. INTRODUCTION; II. THE WELFARE STATE AS THE BASIS OF THE GUIDING PRINCIPLES OF SOCIAL AND ECONOMIC POLICY; III. SOCIAL RIGHTS AS FUNDAMENTAL RIGHTS; IV. THE CONTENT AND THE LEGAL EFFECTIVENESS OF THE RIGHTS INCLUDED IN CHAPTER III OF TITLE I OF THE CONSTITUTION; V. CONCLUDING REFLECTIONS.

\section{INTRODUCTION}

With the affirmation of the democratic principle, the European constitutional doctrine of the second post-war era, accepting the full legislative nature of constitutions, has highlighted a new state model -social and democratic rule of law- based on universal suffrage and on the participation of citizens in the formation of the will of the state and, moreover, on the constitutional guarantee of the effectiveness of fundamental rights. Beside the original principle of formal equality, the social principle of substantial equality, the consolidation of the tasks of the state and the constitutional provision of new and more extensive catalogs of rights (political, civil, economic, and social) are stated.

\footnotetext{
${ }^{1}$ Professor of Constitutional Law, University of Calabria, Italy (fernando.puzzo@unical.it).
} 
Although with different formulas for intensity and latitude for the recognition and for the protection of specific legal situations, it can be said that in the European constitutionalism of the second postwar era a close relationship between advanced conception of democracy, form of state and fundamental rights has been positivized. Very differently from how it was sanctioned in the original liberal constitutionalism, such a relationship is done through the expansion of constitutionally protected legal situations and a new interpretation of the concept of freedom, now tightly integrated with that of equality: a concept of equality which considers as unacceptable the differences based on economic and social relationship, i.e. those based on income capacity. Finally, in such a view the social rights, along with the classical ones of freedom, are conceived as constitutive conditions of the constitutional principle of equality and, at the same time, of the value of the person and their dignity.

However, in the European countries it is not always possible to perceive a positivization of the fundamental social rights as legal situations constitutionally recognized and protected in ways comparable with the so-called negative liberties ${ }^{2}$. Indeed, while civil and political rights are recognized as a common basis of modern democratic states in all European constitutions, only from the constitutionalism after the second post-war era on, with the evolution of contemporary form of state, new fundamental rights, based on the close integration between the notion of freedom and of equality, are stated and as a consequence the social rights appeared. From that perspective, the principles of social justice that inspire contemporary constitutions, by incorporating the "freedom from want" ${ }^{3}$, implement the right to demand the services aimed at ensuring the individual and the citizen a minimum of security and social justice .

Referring to their protection, in the constitutional state of the second world postwar, the rights exist by the constitution, which expresses, as known, something more and different from the law of the liberal state, because in the fullness of its provisions it represents "an essential transformation" ${ }^{4}$ in respect of the previous liberaldemocratic constitutions.

In this perspective, where the ius is no longer lex and the rights are no longer a rule set by the legislature, the constitutions establish subjective claims binding the state in the concrete exercise of its power. The contemporary constitutionalism makes a metamorphosis of the sovereignty of the law into the sovereignty of the constitution, thus transforming the fundamental rights into inviolable rights ${ }^{5}$.

\footnotetext{
${ }^{2}$ Cfr. A. Saccomanno, "Eguaglianza sostanziale e diritti sociali nel rapporto fra ordinamento interno ed ordinamento comunitario" in S. Gambino (Coord.), Costituzione e diritto comunitario. Principi e tradizioni costituzionali comuni. La formazione giurisprudenziale del diritto costituzionale europeo, Milano, 2002.

${ }^{3}$ Cfr. N. Bobbio, “Sui diritti sociali”, in G. Neppi Modona (a cura di), Cinquant'anni di Repubblica italiana, Torino, 1996.

${ }^{4}$ Cfr. F. Balaguer Callejón, (coord.), Manual de Derecho constitucional, 2008.

${ }^{5}$ Cfr. G. Zagrebelsky, Il diritto mite, Torino, 1992.
} 
On this basis the "welfare state" is born, which by sanctioning the primacy of politics over economics in the framework of a model of emancipatory substantial democracy, maneuvers the levers of the economic system and becomes promoter of development, pull factor for production and employment according to the standards of a Keynesian economic interventionism that allows bridle the capitalism in the network of the democracy.

However, it is still possible to perceive the absence of a shared concept on the effectiveness of the rights -particularly the social ones, since many constitutional provisions are different either because of their legal qualification or because of the legal scope of such rights.

Indeed, some European systems, for example, discipline this matter through general clauses (art. 20 Basic Law for the Federal Republic of Germany) or through "Guiding Principles of Social and Economic Policy" (Chap. III EC ), while others -as the Italian Constitution- protect the social rights either through fundamental principles or with specific constitutional provisions.

Although the Spanish constitutional catalog of social rights is extended and has the nature of constitutional rights, the doctrine stresses that the jurisdictional forms of their protection are not always the appropriate for subjective rights, as they are closer to those of the "legitimate interests", since between their prevision and their a legislative and administrative "facere" is needed.

It can be seen that the degree of effectiveness contrasts with their structure of rights, whose degree of effectiveness appears openly insufficient.

Although different arguments have been stated (from economic to political constraints, from the capacity of the judiciary to that of the political system), the leitmotiv that perhaps summarizes all of them is that social rights "cost" and the state has serious problems of taxation, whence the complex problems of financial sustainability of rights in general, and the social rights in particular, derives. The question of the cost of social rights refers therefore to the issue of the structure of such rights as well as to the maintenance of the constitutional state. Nevertheless, as pointed out by accredited doctrine -but also by the very constitutional jurisprudence- the cost of social rights should not impact on the structure of constitutionally guaranteed rights, so the question of the cost of rights is a false problem since it is intrinsic to all constitutional rights and therefore also to the classic ones of freedom ${ }^{6}$.

Moreover, in relation to the question of the legal effectiveness of the so-called programmatic constitutional provisions it seems particularly appropriate to mention the argumentative iter followed by the Italian Constitutional Court ${ }^{7}$ which can be an example for all those systems which have constitutional guarantee clauses of the rights

\footnotetext{
${ }^{6}$ Cfr. G. Lombardi, “Diritti di libertà e diritti sociali”, in Politica e diritto n. 1/1999.

${ }^{7}$ Specially, sentences 1/1956 and 4/1981.
} 
or constitutional provisions on substantive equality and dignity of the person.

\section{THE WELFARE STATE AS THE BASIS OF THE GUIDING PRINCIPLES OF SOCIAL AND ECONOMIC POLICY}

The welfare state in Spain is fully affirmed in the 1978 Constitution $^{8}$, which proclaims it in the art. 1 by means of the formula of "social and democratic state of law" $^{\prime 9}$. The interventionist role of public authorities that defines the welfare state is found firstly in the art. 9.2 of the Constitution, from which the so-called "substantial social principle" (taken from the Italian Constitutional Charter) according to which 'it is for the public authorities to promote conditions so that freedom and equality of individuals and groups to which they belong are real and effective; to remove the obstacles that prevent or hinder their fulfillment and to facilitate the participation of all citizens in political, economic, cultural and social life".

From the letter of the rule that defines the structure of art. 9.2 can be followed, synthetically, that the interventionist dimension of public authorities, strictly speaking, affects three planes of reference: (i) promoting that the conditions for freedom and equality of the individual and the group are real and effective; (ii) the elimination of obstacles that stand to their full enjoyment and (iii) promoting the participation of citizens in the various areas of public life ${ }^{10}$.

The configuration of the social state consists of different regulatory layers, located in different parts of the Spanish Constitution to which specific functions correspond. It is therefore a complex structure that can be synthesized in an essential way through a series of elements: in primis, as a set of values configured as authentic axiological foundation of the state, together with a number of purposes set in programmatic rules which define the main guidelines that should inform the activity of public authorities; another element is the block of social rights and guiding principles of interventionist policies, included in Title I of the Constitution, together with a set of instruments and public powers which, in addition to composing the organic part and the autonomic corpus of Title VIII of the Spanish Constitution, design the economic standards of Title VII; and finally, there are some mechanisms of guarantee and control designed to ensure both the effectiveness of the rights recognized and the effective compliance of the programmatic goals.

\footnotetext{
${ }^{8}$ Among others, cfr. R.L. Blanco Valdés, Introduzione alla Costituzione spagnola del 1978, Torino, 1999 (ult. ed. 2009); M. Aragón Reyes, Constitución y democracia, Madrid, 1989 and G. De Vergottini, Una Costituzione democratica per la Spagna, Milano, 1978.

${ }^{9}$ M.A. Aparicio Pérez, “El Estado social en la jurisprudencia del Tribunal Constitucional”, in G. Cámara Villar and J. Cano Bueso (ed. and coord.), Estudios sobre el Estado social (El Estado social y la Comunidad Autónoma de Andalucía), Madrid, 1993.

${ }^{10}$ F. Balaguer Callejón, "El Estado social y democrático de Derecho. Significado, alcance y vinculación de la cláusula del Estado social”, inn J.L. Monereo (coord.), Comentario a la Constitución socioeconómica de España, Granada, 2002.
} 
From this perspective, social rights are a key element of the constitutional architecture of the welfare state ${ }^{11}$, in that, since all rights are linked to the previous value of human dignity, there are some social rights that are projected as real life support; thus, only from these rights condition of citizenship can be fully exercised. Hence, certain rights such as, education, health and housing, must be assumed as essential elements for access to full status as citizens, so that the different degree of "subjective" enforceability of certain social rights should not involve a their subordinate position, regardless of the economic situation, whether favorable or unfavorable.

From the constitutional point of view, in other words, the normative dimension of social rights can be perceived, although their level of guarantee and protection may have a different degree of coverage, depending on their different location in the constitutional text ${ }^{12}$.

From this perspective, assuming that the constitutional text itself includes most of social rights under Title I, formally calling them as "rights" both in Chapter II - in Sections 1 and 2 - and in Chapter III -although titled as "guiding principles of social and economic policy", also incorporating certain rights expressly named as such- it can be concluded that from the time the Constituent Assembly positivizes the rights, they are considered as genuine rights, whose guarantee level generally depends on the provisions of art. $53 \mathrm{SC}$, which implies that their legal nature cannot be denied ${ }^{13}$.

In short, the fundamental option chosen by the Spanish Constituent Assembly when defining the State $e x$ art. 1.1 SC, is to include the formal and material social clause in combination with the democratic principle and the rule of law.

This formulation, overcoming the liberal model, assumes a finalist social function, designed to ensure and safeguard decent living conditions and, therefore, to have the means to meet the needs of disadvantaged subjects. In other words, it reveals a conception of State which leads teleologically the direction through principles of political nature ${ }^{14}$.

The Spanish Constitution contains provisions legitimizing and guiding the action of the State, so that, in addition to other economic provisions, it determines explicitly rules setting welfare rights as such, others that are projected as directives or mandates to the legislature and others taking the form of statements: in short, a series of rules which, taken together, are fully connected to the principle of substantive equality and therefore to the real and effective equality.

\footnotetext{
${ }^{11}$ J.L. Cascajo Castro, M. Terol Becerra, A. Domínguez Vila, V. Navarro Marchante (coords.), Derechos sociales y principios rectores, Actas del IX Congreso de la Asociación de Constitucionalistas de España, Valencia, 2012.

${ }^{12}$ J.L. Cascajo, La tutela constitucional de los derechos sociales, Madrid, 1988.

${ }^{13}$ G. Pisarello, Los derechos sociales y sus garantías. Elementos para una reconstrucción, Madrid, 2007.

${ }^{14}$ L. Ferrajoli, “Derechos y garantías. La ley del más débil”, Madrid, 2004.
} 
In the very Preamble -in which the objectives aimed at ensuring harmonious coexistence with a fair economic and social order, the progress of culture and the economy, ensuring everybody a dignified life- there are several provisions defining the social state. Indeed this is also evident in the principle of equality, or rather in its indivisible and material aspects (arts. 14 and 9.2), in the welfare dimension of the rights and, in particular, in the recognition of social rights (for example, the right to education, art 27; . the right to protection of health, art. 43); and also in the benefits of the social security system of art. 41, in addition to the consecration of principles on the action of public authorities in economic and social affairs ex arts. 40, 49, 50, 51, and other provisions.

That being so, it should be noted, however, that the core of the contents related to social state are largely in Chapter III of Title I, signed with the phrase "Of the guiding principles of social and economic policy".

The analysis of this regulatory body of the Constitution is problematic because it clearly expresses the social dimension of the state. In other words, the problem of redirecting the content of these norms to legal structures in order to ensure guarantee levels similar to those already configured on the principles and contents of the rule of law and democratic state arises. Moreover, it should be noted that in fact the exercise and guarantee of all constitutional rights depend on public intervention, in the sense that it applies not only to social or welfare rights, but to a greater or lesser extent, to all civil rights recognized in the constitutions. These, indeed, do not escape the need for positive action by the State, measurable in economic or budget terms, by which to ensure their effective protection, so that ultimately we can say that the rights depend on taxes and therefore their protection always involves a cost for public authorities, also with respect to those rights that enjoy a legal cover at the highest level ${ }^{15}$, by virtue of the introduction of the so-called principle of budgetary stability -a consequence of austerity policies applied in times of economic and financial crisis- in the framework of the supreme constitutional principles that inspire and bind the state action.

Accordingly, at the constitutional level it is not possible to appreciate immediately a relatively crystallized model of social state, in the sense that the latter rather than expressing a structural reality of the constitutional order, is projected as a teleological imperative and as such, it is expressive of the tension between social, political and economic forces, and this entails different possibilities of development, but at the same time, many contradictions. Indeed, the guiding principles, although they are firmly grounded from the point of view of value system and enjoy a significant symbolic power of evocation in relation to the articulation of new bases of the political and social organization, however they do not have the normative density of other constitutional provisions, while their nature is that of guiding principles or directive norms, despite that sometimes they are called rights, whose direct and immediate addressee is not the citizen but the public authorities.

\footnotetext{
${ }^{15}$ S. Holmes and C.R. Sunstein, Il costo dei diritti. Perché la libertà dipende dalle tasse, Bologna, 2000.
} 


\section{SOCIAL RIGHTS AS FUNDAMENTAL RIGHTS}

In the framework of the second postwar constitutionalism, to state that rights such as education, equality, health and housing are essential to the democratic and contemporary concept of human dignity ${ }^{16}$ is an assertion that can be shared peacefully; an assertion supported by the Spanish Constitutional Court, which in its case law indicates that in the Spanish Constitution "human dignity is the foundation of political order and social peace". Its legal form is raised to milestone of the constitutional order, needed to build the political order and the social peace. The constitutional concept of human dignity expresses the legal recognition of equality and freedom of all human beings by virtue of being, embodied in those values of the legal order sanctioned in art. 1.1 of the Constitution and which are included in the fundamental rights of Title I. In addition, human dignity -and related rights of art. 10.1 SC- is also identified in the field of health, which as underlined by the Constitutional Court (CC), represents "a value of undoubted constitutional significance" ${ }^{17}$ of "singular importance" ${ }^{18}$ as recently confirmed by the jurisprudence of the German Constitutional Court, whereby the legal obligation would come from the fundamental right to dignified existence, deductible from the human dignity of art. 1 and the principle of the social state ex art. 20.1 of the German Constitution (judgment of the German Constitutional Court of February 9, 2012).

As known, therefore these are not "classic rights of freedom," whose negative dimension is manifested in creating a protective barrier against possible illegal interference of the State but rights whose nature is to provide social benefits, that is, rights which obligate the State to guarantee a certain service or a particular good for citizens ${ }^{19}$.

However, at the constitutional level, as already noticed, all rights are not covered by the same legal status, so the problem arises of which are the consequence of this differentiation. In this regard, we should remember that the CC has stated that "the protection of family, health maintenance and adequate and dignified housing, values which together with sufficient social benefits in situations of necessity that must be guaranteed a public social security, are constitutionally enshrined in the arts. 39, 41, 43 and 47 of the Constitution, and force public authorities, not only to the deployment of the corresponding administrative action." ${ }^{20}$ In other words, it can be drawn that for their protection, although these are legal rights, it is not decisive that they may be enforceable before the ordinary judge in the more or less extensive forms established by the legislature, as this argument would lead to give the law the role of to recognize a right which instead preexists it, since it has been foreshadowed in the Constitution establishing its existence, letting the law to determine its extent.

\footnotetext{
${ }^{16}$ STC 86/1985, FJ 8.

${ }^{17}$ ATC 96/2011

${ }^{18}$ ATC 239/2012

19 Abramovich and Courtis, Los derechos sociales como derechos exigibles (Prologue by L. Ferrajoli), Madrid, 2002.

${ }^{20}$ STC 113/1989.
} 
Moreover, it should be clear that, regardless of their form, the recognition of these rights in the SC shows the concern of the Constituent Assembly to put the person and their rights in the center of the legal and political construction of the State. Therefore a State that cannot be passive, but on the contrary, considers as a foundation of political order the personal dignity, so that it cannot be indifferent to the social, economic and cultural conditions in which the lives of the citizens operate. In short, a constituted State which is obliged to "promote the conditions so that the freedom and equality of individuals and groups are real and effective." In this regard, the Constituent Assembly has designed two guidelines because, on the one hand, has imposed on public authorities a specific role which has, given its binding nature, an effectivity of all mandatory and enforceable rights and, on the other, it has foreshadowed the purposes to which public authorities should aim, which retain respect to the latter a wider leeway, and therefore adscribing to the category of the guiding principles.

From this point of view, the normative density concerning the compulsory promotion of the liberty and the equality is variable, depending on whether it is a fundamental right rather than a guiding principle. But if we look at the rights mentioned at the beginning, it is evident that the first two, i.e., education and equality, are fundamental rights included in Chapter II of Title I SC, while the other two, health and housing, fall within the scope of the guiding principles of Chapter III of the same title, so that the differential legal status for rights and principles refers to the problem of their direct legal effectiveness and, ultimately, to the issue of their virtuality for citizens ${ }^{21}$.

It should be remembered that the Constitution is also a legal document ${ }^{22}$, consisting of several parts, which are binding both for public authorities and for citizens. On this basis, therefore, it is possible to note that the guiding principles of social and economic policy materialize their effectiveness in the democratic state, from their very legal nature, ie from their role of informing principles of the action of the public authorities, whose effectiveness can be controlled both legally and politically.

In addition, leaving aside the legal force of the guiding principles which we will discuss below, it should reflect on the direct impact of fundamental rights in the social state $^{23}$.

From this point of view, we can say generally, that fundamental rights and therefore also those with social content, are effective with respect to all public authorities; therefore their normative virtuality depends on the will of the Constituent Assembly, in the sense that ensuring their protection and effectiveness does not require the action of the Legislature, while those with social content (such as the right to

\footnotetext{
${ }^{21}$ L. Prieto Sanchís, "Derechos sociales y el principio de igualdad sustancial”, in Revista del Centro de Estudios Constitucionales n. 22/1995.

${ }^{22}$ E. García de Enterría, La Constitución como norma y el Tribunal constitucional, Madrid, 1985, (III ed.).

23 J.J. Solozábal, "Una revisión de la teoría de los derechos fundamentales”, in Revista Vasca de Administración Pública n. 58/2000.
} 
education or the right to health, which have a different legal status) require the interpositio legislatoris and the administrative facere in order to develop their content.

From this perspective, the original question about welfare social rights as fundamental rights embodied in the various constitutions arises, together with the classic fundamental rights, so, due to their different foundations, fundamental social rights are connected with the realization of the principle of real and effective equality, while the classic fundamental rights are linked to the achievement of the principle of freedom. This doctrinal debate, today, refers to the issue of justiciability of social rights and that of the constitutional protection of their essential content which, from the Spanish perspective, is linked to the legal status of fundamental rights as justiciable rights not only against the administration, but also against the legislature, so that their protection includes also the guarantee of a minimum content restricted, plus an equal recognition.

From the subjective perspective, fundamental social rights are protected by the ordinary courts, through a preferential and summary process and, where appropriate, by the Constitutional Court. In summary, therefore, we can say that they are subjective rights endowed with a particular resistance against the legislature, as the binding nature of fundamental rights makes them spaces of freedom and welfare resistant to any possible type of impairment. Hence the legal nature of fundamental rights is extensible to fundamental social rights, so the welfare content of these rights become mandatory and therefore are enforceable, regardless of social, economic and political circumstances.

Regarding social rights within the scope of the principles, their content assumes the function of informing the positive legislation and judicial practice, and so they can qualify as rights strictu sensu, they require legislative implementation and therefore are enforceable before the judicial authority. In conclusion, taking into account the different legal status, it can be stated that through the fundamental rights the Constituent Assembly configures a part of the social state and through the principles prefigures it, forwarding to the legislature its final configuration.

\section{THE CONTENT AND THE LEGAL EFFECTIVENESS OF THE RIGHTS INCLUDED IN CHAPTER III OF TITLE I OF THE CONSTITUTION}

As already stated, it is necessary to underline that the norms contained in Chapter III of Title I of the Constitution are quite heterogeneous since it is possible to distinguish norms that identify rights expressly called as $\operatorname{such}^{24}$, in addition to duties ${ }^{25}$. Other provisions are mandated to the legislature, both in terms of punitive provisions of

\footnotetext{
${ }^{24}$ As, for example, the right to the protection of health ex art. 43.1, or the right to culture in art. 44.1, or the right to decent housing in art. 47, and also the right to enjoy an adequate environment in art. 45.1.

${ }^{25}$ As, for example, the duty of parents to attend their children (art. 39) or the duty to protect the health (art. 43.2) and the duty to protect the enviroment (art. 45.1).
} 
administrative and criminal relevance ${ }^{26}$, and as specific mandates ${ }^{27}$. Finally, there are norms that set principles designed to guide the actions of public authorities in order to achieving general purposes, which by stating their programmatic nature are fully consistent with the meaning of the heading 'guiding principles' and which however can be differentiate by their vagueness and incompleteness regarding means, conditions and requirements, as can be seen emblematically in the content of art. 40.1, which states that "public authorities shall promote favorable conditions for social and economic progress and for a more equitable distribution of regional and personal income within the framework of a policy of economic stability."

However, in order to systematize their content, guiding principles can be grouped taking into account the objectives pursued and which are subject to protection.

Firstly, we can distinguish guiding norms establishing objectives or general purpose of state action; for example, it is significant the formulation linking the public authorities to the promotion of "the favorable conditions for social and economic progress and for a more equitable distribution of the regional and personal income within the framework of a policy of economic stability" with the intention of achieving full employment oriented politics in art. 40.1, which, as noted by the constitutional jurisprudence, in the collective dimension is combined with the right to work ex art. $35.1 \mathrm{SC}^{28}$. Another example of guiding norm of general purpose is in art. 44.2 SC, according to which "the public authorities shall promote science and scientific and technical research in the general interest", developed by the legislature by Law 13/1986 of Promotion and General Coordination of Scientific and Technical Research.

Along with this type of regulations, there are guiding norms on the protection of certain goods of general interest, among which the content of art. $45.2 \mathrm{SC}$, which states that "the public authorities shall ensure the rational use of all natural resources, in order to protect and improve the quality of life and to preserve and restore the environment, relying on the indispensable collective solidarity". With this norm the Constituent Assembly states a mandate to the public authorities intended to protect the environment, combining harmonically the rational economic use of natural resources with environmental protection. These constitutional purposes aimed at protecting the environment, on the one hand refer to the necessary systematic interpretation in relation to other principles and rights such as the right to property, free enterprise and the principle of the free movement of goods and ${ }^{29}$, and on the other hand, being a matter of transversal nature, the environment can determine the exercise of other material powers, as the management of the territory, fishing, etc. ${ }^{30}$.

\footnotetext{
${ }^{26}$ As in relation to environment (art. 45.3) or in relation to the protection of the cultural, artistic and historical heritage (art. 46).

${ }^{27}$ As, for example, in relation to foreign trade (art. 51.3) and the professional associations (art. 52), or also as previsions of institutional guarantee, in relation to the establishment of a public regime of Social Security (art. 41) or in relation to the family (art. 39).

${ }^{28}$ STC 22/1981, FJ 8.

${ }^{29}$ SSTC 227/1988, FJ 7, and 243/1993, FJ 5.

${ }^{30}$ STC 36/1994, FJ 3.
} 
The norm in art. 46 SC can be included in this type of guiding norms. According to it "public authorities shall guarantee the preservation and shall promote the enrichment of the historical, cultural and artistic heritage of the peoples of Spain and of the goods comprised in it, whatever their legal status and their ownership" from where the possibility of introducing limits and authorizations for the sale and transfer of goods of "cultural interest" is inferred ${ }^{31}$.

In addition, Chapter III includes norms aimed at the protection of persons, by ensuring a vital existential minimum, especially with regard to the protection of workers; indeed based on art. 41 SC "public authorities shall maintain a public Social Security system for all citizens guaranteeing adequate social assistance and benefits in situations of need, especially in case of unemployment". It is therefore clear that this provision expresses a central profile of the welfare state, as it prefigures the existence of a system of public social protection as a necessary institutional guarantee ${ }^{32}$, by which the mentioned constitutional principles designed to protect citizens in case of necessity and unemployment are concretized.

In short, as noted by the Constitutional Court, Social Security should be seen as a "necessary function of the social and democratic rule of law" ${ }^{13}$ in the sense that situations of need are assigned to the minimum care constitutionally guaranteed, to which other contributory benefits can be attached: it is therefore unavailable for the legislature, because, although these rights have a legal configuration and therefore are susceptible to be modulated by this ${ }^{34}$, the legislature is obliged to maintain a public Social Security system in recognoscible terms for the image the social conscience in every time and place has of it.

In addition, obviously, it assumes particular importance the provision contained in Chapter III, by which the right to health protection is recognized in the art. $43.1 \mathrm{SC}$, with respect to which the jurisprudence itself uses an integrating interpretation, given their intrinsic nature of essential human need ${ }^{35}$. Under this norm, paragraph 2 states that "it is the responsibility of the public authorities to organize and safeguard public health through preventive measures and the necessary benefits and services. The law shall establish the rights and duties of all in this respect”36, hence, as stated in the

\footnotetext{
31 STC $17 / 1991$.

${ }^{32}$ STC 37/1994, FJ 3d.

33 STC 65/1987, FJ 17.

34 STC 37/1994, FJ 3.

35 About the right to health cfr. J.J. Ruiz Ruiz, "El derecho a la salud en la actual crisis económica: los límites constitucionales a los recortes de prestaciones sanitarias y las exigencias de sostenibilidad del gasto social”, in S. Gambino (coord.), Diritti sociali e crisi economica. Problemi e prospettive, Torino, 2015.

${ }^{36}$ About the universalization of the health benefits, cfr. specially the art. 3.2 of Ley General de Sanidad de 1986 and, more recently, after the economic recession and the y, más recientemente, tras la recesión económica y the emergence of the fiscal and budgetary crisis, the abundant emergency legislation and, in particular, the Real Decreto-Ley 16/2012.
} 
constitutional jurisprudence, it follows the necessary existence of a national health regulatory system (National Heal System) ${ }^{37}$.

Other norms contained in Chapter III are intended for the protection of persons as belonging to certain social groups, such as children (art. 39.4) or youth (art. 48), elderly (art. 50) or disabled persons (art. 49). Finally, there are norms connected with the requirement of protection of human dignity, aimed at people who demand tangible and intangible goods necessary for the free development of the individual, such as the aforementioned right to health and access to culture (art 44.1), or the right to decent and adequate housing (Article 47) others aimed at the specific protection of the rights of workers (Article 40.2); and finally other norms aimed at the social, economic and legal protection of the family (art. 39.1), understood, as noted by the Constitutional Court, in a broad sense, so that the protection is not limited to that which is born from the marriage of art. $32^{38}$.

That having been said, we must now examine both the value and the legal effectiveness of the rights and principles that guide the action of the public authorities in Chapter III.

First of all, it should be noted that, in the case of constitutional norms, there is no doubt that, under art. 9.1 SC, they have legal force, regardless of the specific scope of the constitutional regulatory structure. It seems clear that, in the case of guiding norms aimed to pursue the objectives of the political organization established in the Constitution, they comprise regulated values and criteria and, therefore, represent data of the system intended to their achievement and interpretation. It follows that the socalled "guiding principles" ${ }^{39}$ cannot be understood as mere programmatic proclamations or be treated as if they were pure "constitutional rhetoric."

Such a position has been held from the point of view of constitutional interpreter, for which "from that perspective, it should be recalled that the guiding principles of social and economic policy, among which is the aforementioned provision, are not mere norms without content (STC 19/1982, FJ 6) but, as far as the courts are concerned, their decisions must be informed by their recognition, respect and protection, as provided for in art. $53.3 \mathrm{SC}^{40}$.

Beyond the obvious connections with the social, democratic and lawful character of the Spanish State, the legal effectiveness of these principles can be found, in primis, in the content of art. 53.3 SC, which states that "recognition, respect and protection of the principles recognized in the Third Chapter shall guide legislation, judicial practice and actions of public authorities. They may only be invoked before the ordinary courts in accordance with the provisions of the laws that implement them" from which a mandate to the legislature which does not deprive of normative effectiveness the content

\footnotetext{
${ }^{37}$ STC $211 / 2014$ FJ 4.

${ }^{38}$ SSTC 222/1992, FFJJ 4 y 5, 47/1993, FJ 2, 116/1999, FJ 13.

${ }^{39}$ J. Tajadura Tejada (dir.), Los principios rectores de la política social y económica, Madrid, 2004.

40 STC 95/2000.
} 
of the right in question, since it imposes to legislate favorably to the guaranteed content, which can ultimately lead to an appeal of unconstitutionality ex art. 161.1 SC, although considering social rights as norms does not amount to assert their justiciability.

At the constitutional level, it can be firstly seen see that the norms expressly qualified as rights per se do not constitute subjective rights directly justiciable, but only legal situations enforceable before the courts, based on the scope of the laws that develop them in the legal level, anchoring them in the aforementioned constitutional foundation. In short, their effectiveness is not immediate or direct, but deferred and mediate as set out by the legislature, respecting the design prefigured by the Constituent Assembly, so it follows that they do not have the normative structure of the rights, but they are guiding principles susceptible of development by the legislature, configured so as rights that potentially have a plural configuration ${ }^{41}$. From this point of view, although it is not possible to recognize a full legal and constitutional protection, as in the case of the right to health covered by the guiding principles of Chapter III, it can be said that it is not possible to deny forcibly their nature and this implies, on the one hand, that a certain degree of enforceability can be protected jurisdictionally and, secondly, that the nature of constitutionally recognized right implies the existence of a content and that determining such content corresponds to the legislature.

Regarding the effectiveness of such rights regarding the legislature this can be seen as a consequence of the mandate that requires their development, recognition, respect and protection, that the legislature is primarily called to give concreteness to such guiding principles and therefore also the other powers are obliged to respect the law under the provision of the democratic principle and the system of sources. This dimension is particularly reinforced at the constitutional level as it is accompanied by a specific institutional guarantee, as for example, in the articles 39 (protection of the family) and 41 (public social security system), which foreshadows a unavailable core for the legislature itself. However, regardless of such a significant and important feature, not being provided regarding the legislature the limit of respect for the essential content, it seems clear that the margin of discretion with respect to its configuration, is quite broad according the general concepts and terms used by the Constituent Assembly.

As for the extent of the possible configuration, important issues arise: firstly, the issue concerning the possible remedy in case of abstention or inactivity of the legislature and, secondly, the question concerning the so-called principle of irreversibility, i.e., the possibility of understanding the contents of the guiding principles previously recognized assuming them as irreversible level of guarantee and, therefore, as binding the legislature.

In accordance to the first point, ie the complex problem of "unconstitutionality by omission", it is sufficient to note that the Constitutional Court has not got

${ }^{41}$ STC 206/1997. 
instruments to force the legislature to act in the case of an "absolute omission", that is, if there is not supplement or development legislation.

However, in the exercise of judicial review of legislative acts, in line of principle it might be accepted the possibility of control by the Constitutional Court as a result of an " relative omission" in the event that the relevant legislative regulation is incomplete. However, given that the legislature is not subject to respect the "essential content", as noted by constitutional jurisprudence ${ }^{42}$, this hypothesis refers to the problem of identifying what may be the control parameter regarding the alleged incompleteness, in addition to the intrinsic "vagueness and uncertainty" that define the guiding principles themselves. All this, however, does not close the possibility that such control can be exercised in the event that the principle of equality or the right to effective judicial protection come into play or even that can be exercised under other objective guarantees offered by the constitutional order, but in that case, these latter rights and guarantees in the context of a systematic interpretation would be those which would be placed as a parameter of judicial review, and the reference would not be only to the guiding principles.

As for the so-called theory of the "irreversibility" of the content of social rights, which involves crystallizing the content of the rights already recognized by the legislative regulation, it has been adopted as a constitutional guarantee ${ }^{43}$, it could contravene the democratic and the political pluralism principles, since it would limit the free exercise of discretionary policy options in economic and social realms. However, the respect for the principles that define the social state admit the need to guarantee the essential minimum content established through legislative development. In this sense, the Constitutional Court, invoking the right to equality -in line with the prohibition of discrimination based on sex- has stated that "given the social and democratic character of the rule of law that our Constitution stands and the obligation imposed to the State by the arts. 9.2 and 35 of the Constitution to promote that the conditions for equality of individuals and groups are real and effective and the promotion through the work, but in no case can there be discrimination on grounds of sex, it can be understood that the worker cannot be deprived of the already achieved social conquests without enough reason to do so" ${ }^{44}$. Furthermore, the application of the principle of irreversibility -or of no regression social benefits- can be seen as a control of reasonability of a reform in peius of social benefits contrary to the principle of proportionality and equity or no unenforceable due to supervening circumstances ${ }^{45}$. From another point of view, another limit and interpretive instrument can be inferred from the constitutional dictate of art. 31.2, according to which "the public expenditure shall make an equitable allocation of public resources, and its programming and execution shall comply with the criteria of

\footnotetext{
42 About the nature of such principles, cfr. STC 45/1989, FJ 4, where it is stated that «it is unlikely that any legal norm can be considered unconstitutional by omission, that is, for not fulfilling, isolately considered, the mandate of the public authorities and, specially, that of the legislature, where each one of these principles is generally concreted».

${ }^{43}$ SSTC 134/1987, FJ 5, and 184/1990, FJ 5.

${ }^{44}$ STC 81/1982, FJ 3.

45 SSTC 136/2012, FJ 5, 71/2014, FJ 7b and 85/2014, FJ 3c.
} 
efficiency and economy" which seems to impose in a finalist way the sense of the redistributive effect of public expenditure.

Finally, regarding the legal effectiveness, since the Spanish Constitution generally refers to the recognition, respect and protection of the guiding principles that should inform the action of public authorities, it appears that government and administration are bound by those norms, both in the exercise of the management function and in the exercise of normative authority itself. The same is true with respect to judicial organs, as also constitutionally judicial practice must be informed by these principles, so that both the interpretation of the norms and their application, cannot be outside the guiding principles. Regarding the latter, a fortiori, suffice it to recall that this constitutional requirement is also reinforced by art. 5.1 of the Organic Law of the Judiciary, which states that judges and courts interpret and apply the laws and regulations "according to the precepts and constitutional principles", according to their interpretation by the Constitutional Courts, so that from this view, there arises the possibility that the courts use these principles as a constitutional parameter to raise any questions of unconstitutionality.

\section{ConCluding Reflections}

In the Spanish constitutional order most of welfare social rights are presented as formal rights and materially conditioned by the concrete development made by public authorities and therefore their immediate enforceability before the ordinary judge is limited by the constitutional provision of art. 53.3.

Such an arrangement, according to the jurisprudence of the constitutional court implies, on one side, a derogation of the obligatoriness of the Constitution, since it affirms that "the constitutional principles and fundamental rights and freedoms are binding on all public authorities (arts. 9.1 and 53.1 SC) and are immediate source of rights and obligations and not mere programmatic principles. The very fact that our basic norm in art. 53.2 provides a special system of protection before the Constitutional Court, which extends to conscientious objection, is but a confirmation of the principle of immediate applicability. The only exceptions of this general principle are the cases where so impose the Constitution itself (i.e. the guiding principles of Chapter III) or when the very nature of the norm prevents considering it immediately applicable ${ }^{46}$.

It follows that the Constitutional Court may control a violation of the Constitution by omission of legislatively developing a constitutional norm, thus ensuring the protection of those subjective legal situations, at least in terms of their essential minimum.

Although welfare rights can be invoked before the ordinary courts in accordance with the terms laid down in the laws that develop them, it seems possible to find a

${ }^{46}$ STC $15 / 1982$. 
constitutionally consistent interpretation by the ordinary judge, which could pose a appeal of unconstitutionality on the limits of the law of development approved by the public authorities, based on a parameter that systematically combines several constitutional provisions (Preamble, art. 1.1 of the Preliminary Title, Guiding Principles of Chap. III Tit. I, art. 9.2 and art. 14 EC).

Such systematic and evolutionary interpretation, as already noted, already used by other European constitutional courts, could rely on the arguments by the supreme interpreter when, in discussing the nature of the guiding principles of social and economic policy, states that "it is unlikely that any law can be considered unconstitutional by omission, that is, for not respecting, in isolation, the mandate of the public authorities and, in particular, the legislature, in which each of these principles is usually concreted" ${ }^{47}$.

However, from this interpretive perspective, according to an attentive doctrine, "not prevent, obviously, the possibilities of control that might result from the coming into play the principle of equality, the right to effective judicial protection or any objective guarantee provided by the constitutional order, but in these cases these rights or guarantees would be the constitutional control parameter within a systematic interpretation and not, by themselves, the guiding principles" ${ }^{48}$. In that sense, for example, the right to vital minimum ${ }^{49}$ could be configured from the right to life (art. 15), from the principle of the social State (art. 1.1.) ${ }^{50}$, in relation to the dignity of the person (art. 10.1) and also from some guiding principle such as the right to the protection of health (art. 43), to adequate housing (art. 47).

Even more, referring to social rights the Spanish constitutional jurisprudence, as the Italian, does not accept the thesis of the programmatic nature of constitutional norms, stressing that "the Constitution is just that, our supreme law and not a programmatic or main statement; this is something affirmed unequivocally and generally in the art. 9.1 which states that "citizens and public authorities are subject to the Constitution" as well as that "repeated decisions of this Court as supreme interpreter of the Constitution (art. 1 LOTC) have declared that indubitable value of the Constitution as a norm" ${ }^{51}$. Regardless the immediate obligatoriness of some constitutional provisions, included in Chapter II, "Rights and Freedom" (articles 14-38), which do not need mediation of the ordinary legislature and are directly effective without legislative development, paraphrasing the Constitutional Court: "if it is true that such value needs to be modulated with regard to the arts. 39-52 in the terms of art. 53.3 of the Spanish Constitution, there can be no doubt about the immediate binding nature

\footnotetext{
${ }^{47}$ STC 45/1989.

${ }^{48}$ Cfr. F. Balaguer Callejón, (coord.), Manual de Derecho constitucional, 2008, (III ed.).

${ }^{49}$ Cfr. P. Tenorio, "El Tribunal Constitucional, la cláusula del Estado social, los derechos sociales y el derecho a un mínimo vital digno”, in AAVV (Actas IX Congreso de la ACE), Derechos sociales y principios rectores, Valencia, 2012.

${ }^{50}$ In relation to the legal fundamental values and principles in which the Spanish democratic and social rule of law is founded, in particular: SSTC nn. 4/1981, 15/1982, 16/1982, 77/1982, 80/1982, 7/1983, 8/1983, 15/1983.

${ }^{51}$ STC n. 80/1982.
} 
(i.e., without mediation by the ordinary legislature) of the arts. 14-38, components of the second chapter of the first title, as the first paragraph of art. 53 states that the rights and freedoms set forth in this chapter are binding on all public authorities. That the exercise of such rights has to be regulated only by law and the need for it to respect their essential content, mean that these rights already exist, and are binding on all public authorities including obviously the judges and magistrates members of the judiciary (art. 117 EC), from the very moment of the entry into force of the Constitution. One of such rights is equality before the law of all Spaniards, there may be no discrimination between them on grounds of birth (art. 14 EC)" ${ }^{52}$.

Furthermore, as a part of the doctrine supports, other constitutional provisions, those concerning the "guiding principles of social and economic policy" (arts. 39-52) need a legislative modulation in accordance with the provisions of art. 53.3 SC in response to their "different legal effectiveness" ${ }^{53}$.

However, in consideration of their nature of general constitutional provisions, such rights and principles as a whole are directive to the action of the legislature as well as hermeneutical criterion and parameter for the judges in the exercise of the judicial function. It is, in short, a set of fundamental principles and values that the Constituent Assembly of 1978 believed suitable to recognize constitutionally while assuring the courts and judges a deep elasticity, which was necessary in view of the concrete conformation in Spain to the deep historical, economic and social changes already experienced over decades in other European countries.

However, from the beginning of the new millennium ${ }^{54}$ the complex architecture of contemporary constitutionalism, to which largely the achievements in terms of civilization and social justice are due, seems today to crack because of many forces and trends of varied nature that make waver forms and ways of being of the democratic, social, legal and constitutional state, and that until yesterday were assumed to be firm and definitive as inherent to the idea of democracy conceived as heritage of everyone ${ }^{55}$.

In this context, it is evidently that the most acute problems of the crisis concern especially to the welfare state model.

In Spain the development and crisis of the welfare state model have elements of continuity with other European systems, and especially, the countries of the

\footnotetext{
${ }^{52}$ Ibidem.

53 Among others, cfr. E. García de Enterría, La Constitución como norma y el Tribunal constitucional, Madrid, 1985, (III ed.) y Jiménez Campo, “Estado social y democrático de derecho”, in Diccionario del sistema político español, Madrid, 1984.

${ }^{54}$ Cfr. M. Luciani, “Integrazione europea, sovranità statale e sovranità popolare. Norme e idee”, inn Istituto Enciclopedia Italiana, XXI secolo. Norme e idee, Roma, 2009, Vol. I.

${ }^{55}$ Cfr. M. Luciani, “Integrazione europea, sovranità statale e sovranità popolare. Norme e idee”, in Istituto Enciclopedia Italiana, XXI secolo. Norme e idee, Roma, 2009, Vol. I., ove secondo l'Autore "l'idea che la crisi della sovranità sia un problema solo per gli stati non è accettabile ... essa è un problema innanzitutto per le persone perché senza sovranità i loro diritti politici (e non solo) non sono garantiti e le politiche redistributive non si possono attuare”, p. 164.
} 
Mediterranean area, exacerbated by the economic and financial crisis and the relative political and constitutional answers both on the national and on that European realm ${ }^{56}$. On the basis of the crisis in the social, democratic and legal constitutionalism, a central relief is occupied by the consequences of the economic crisis linked to the limits on public expenditure and, therefore, to the availability of public resources needed for ensuring the exercise of the functions of the welfare state ${ }^{57}$, on the loss of centrality of parliamentary decision respect to the demands, now constitutionalized, of levelling the balance of the state and, ultimately, on the effectiveness of human rights ${ }^{58}$.

In such a scenario, the welfare state, born to guarantee freedoms and rights in the constitutional perspective of realizing the goals of social justice, due to degradation / evanescence of social rights eventually makes fragile the democracy itself, ignoring the normative value the constitutional text.

But do not forget that, although in different ways, the European constitutions of the last post-war, beyond procedural rules, are substantive rules regarding the very content of the laws. In other words, it is in the normative conception of the Constitution, as norm and limit of the legislative acts, where its superiority is located ${ }^{59}$. Show, by assigning direct binding nature to the fundamental principles and norms, it is the most innovative and original aspect of the contemporary constitutionalism and, at the same time, reflects the historical requirement of not leaving the system of freedoms and rights to the mere realization of principle of legality but of making it an instrument of guarantee and direction in addition of protection and promotion.

Finally, the problem of the welfare state (in Spain and other European countries) basically concerns not only the general taxation, but also the very representative quality of the democracy and, therefore, in order to the adequacy of the protection of the represented interests represented, in short, it depends on the effectiveness of the democratic principle.

The reduction of available resources also endangers the very justiciability of fundamental rights, not only the social ones. Such a risk, however, seems even more

\footnotetext{
${ }^{56}$ Cfr. F. Puzzo, "Il costituzionalismo dei diritti sociali e la sovranità finanziaria statale, ovvero dalla novella costituzionale sul c.d. 'Federalismo fiscale' al Trattato europeo sul c.d. 'Fiscal Compact', passando per la Legge cost. n. 1/2012 sul principio del pareggio di bilancio”, in S. Gambino (coord.), Diritti sociali e crisi economica. Problemi e prospettive, Torino, 2015.

${ }^{57}$ Cfr. S. Gambino (coord.), Diritti sociali e crisi economica. Problemi e prospettive, Torino, 2015, and in particular S. Gambino, "Crisi economica e diritti sociali (con particolare riguardo al diritto alla salute, all'assistenza sociale e all'istruzione)", G. Ruiz-Rico Ruiz, "El valor de los derechos constitucionales en tiempos de crisis”, J. Lozano Miralles, “Universidad y crisis económica: el caso español”.

${ }^{58}$ Cfr. M. Luciani, "L'equilibrio di bilancio e i principi fondamentali: la prospettiva del controllo di costituzionalità", in www.cortecostituzionale.it, 22/XI/2013, A. Spadaro, "I diritti sociali di fronte alla crisi (necessità di un nuovo «modello sociale europeo»: più sobrio, solidale e sostenibile" en Rivista AIC n. 4/2011 (www.rivistaaic.it); C. Salazar, "Crisi economica e diritti fondamentali", in Rivista AIC n. 4/2013; A. Ruggeri, "Crisi economica e crisi della Costituzione”, in AA.VV., Scritti in onore di Antonio D’Atena, Milano, 2015.

${ }^{59}$ Cfr. E. García de Enterría, La Constitución como norma y el Tribunal constitucional, Madrid, 1985, (III ed.) and V. Crisafulli, “La Costituzione e le sue disposizioni di principio”, Milano, 1952.
} 
pervasive because of the provisions introduced in the new art. 135 of the Spanish Constitution (and similarly on the reform of article 81 of the Italian Constitution) which makes the enforceability of fundamental rights in monetarily conditioned rights, which leads to discharge on judges of final recourse -Constitutional Court, Court of Justice of the European Union and the European Court of Human Rights- the decision on the balance between financial sustainability and effectiveness of social law. 